1 During the last decade, economists have attempted to identify Sticky Floors in the labour market, 2 thereby building on the seminal work by Booth et al. (2003). Sticky Floors can be described as

3 the pattern that women are, compared to men, less likely to start to climb the job ladder. Thereby

4 Sticky Floors complement the well-known concept of Glass Ceilings which implies that women 5 are less like to reach the top of the job ladder. ${ }^{1}$ Evidence for the existence of Sticky Floors has 6 been found in countries such as Italia (Filippin and Ichino, 2005), Spain (Gradín and del Río, 7 2009), Thailand (Fang and Sakellariou, 2011) and the United States (Baker, 2003). In Belgium, 8 the country where the present study is accomplished, Deschacht et al. (2011) conclude, based on 9 their discrete time event history analysis of the Panel Study of Belgian Households data (199410 2001), that women near the top face fewer obstacles to promotions than women in the lower- and 11 mid-career levels. In addition, Belgium is one of the 12 European countries in which 12 Christofides et al. (2013), investigating the gender wage gap across 24 EU member states, found 13 evidence for Sticky Floors.

14 From a policy perspective, it is important to determine the nature of the phenomenon of Sticky Floors in order to design adequate policy actions. Based on the mentioned literature, 16 however, it is unclear whether Sticky Floors result from gender differences in human capital, 17 preferences and behaviour at the employee side or from preferences (and unequal treatment) at the employer side. In our study, we contribute to the literature by investigating the importance of employer preferences (and thereby discrimination) in explaining Sticky Floors, keeping

21 More concretely, we aim at answering the question whether unequal treatment of equally 22 productive male and female job candidates by employers is heterogeneous by whether or not

\footnotetext{
${ }^{1}$ See Albrecht et al. (2003), Arulampalam et al. (2007), Booth (2009), Kassenboehmer and Sinning (2014), Reuben et al. (2012), Smith et al. (2013) and Weinberger (2011) for some seminal and recent contributions to the literature on Glass Ceilings. In addition, see Blau and DeVaro (2007), Matteazzi et al. (2014) and Yap and Konrad (2009) for more general contributions on gender differentials in promotions.

${ }^{2}$ Throughout this article the terms "employer preferences" and "employer discrimination" are used to point to the general concept of unequal appraisal and treatment of women and men in the labour market in respect of employers. Therefore, these concepts do not refer to the narrower theoretical concept of Becker’s (1957) “employer discrimination”.
} 
1 they apply for jobs implying a (first) promotion. ${ }^{3}$ Unfavourable treatment of females in the access to these positions can be expected based on the theoretical models of discrimination introduced by Becker (1957) and Arrow (1973). ${ }^{4}$ Discrimination against women applying for

4 higher positions could result from the general distaste that employers, co-workers and customers may have to collaborate with women in these higher positions, potentially related to the traditional overrepresentation of men in these positions. Furthermore, employers could expect a

7 higher average productivity from males relative to females in leading positions. This may relate to the match between these positions and more "masculine" characteristics such as dominance, autonomy and assertiveness on the one hand ${ }^{5}$ and the fact that females are documented as having, on average, a less continuous and committed labour market participation related to the traditional division of labour within the household and maternity leave (Baumle, 2009;

12 Blandford, 2003; Budig and England, 2001; Romeu Gordo, 2009). In addition to the theoretical 13 support by the frameworks of Becker (1957) and Arrow (1973), potential gender discrimination 14 by employers when taking hiring decisions implying a promotion for the job candidate squares with the notion in the popular literature that men are promoted based on potential, while women are promoted based on prior performance (Carter and Silva, 2011).

17 To the best of our knowledge, all former studies on gender differences in promotion opportunities have used regression-based methods on observational data (typically household survey or labour force data). The most common approach consists of Oaxaca-Blinder style decompositions of wage differentials in a part explained by observables related to human capital

\footnotetext{
${ }^{3}$ This implies that we do not investigate unequal treatment in promotions within the firm. We come back to this issue later.

${ }^{4}$ These theories are based on neoclassical assumptions and have been criticised concerning different aspects - see, e.g., Bergmann (1989) in the context of gender based discrimination in the labour market. In spite of the development of alternative approaches to theorising discrimination such as the models of opportunistic discrimination, implicit discrimination, noncompeting groups and lexicographic search by employers (Altonji and Blank, 1999; Bertrand and Mullainathan, 2004; Darity and Mason, 1998), however, many recent contributions to the discrimination literature are still guided by the theoretical framework of the models of taste-based and statistical discrimination (Borjas, 2009; Charles and Guryan, 2008). Moreover, while some newer models are particularly applicable to the case of ethnic discrimination, the models of Becker (1957) and Arrow (1973) can be applied to the case of gender discrimination in a natural way.

${ }^{5}$ For instance, Oakley (2000) argues that the less assertive forms of communication by women might be inappropriate for functioning in the upper echelons of many corporations.
} 
1 and occupational characteristics and an unexplained part pointing in the direction of 2 discrimination (Oaxaca, 1973; Blinder 1973). Residual gaps at the top of the wage distribution 3 are interpreted then as complementary with the Glass Ceiling concept while residual gaps at the 4 bottom of the wage distribution point in the direction of Sticky Floors. In their survey of 5 experimental advances in the study of gender differentials in the labour market, Azmat and 6 Petrongolo (2014) formulate two important drawbacks of using observational data to measure 7 gender discrimination. First, most observational data do not capture some of the determinants of 8 a workers productivity (e.g. motivation and intrinsic ability) which may be observed - and 9 valued - by employers. Stated otherwise, based on these non-experimental data, researchers 10 cannot control all variables employers take into account when making their hiring and 11 remuneration decisions. As a result, no conclusive evidence of discrimination can be provided 12 based on these data. Second, if pre-market investments in human capital or decisions to apply for 13 a job implying a promotion are affected by the expectation of future labour market 14 discrimination, the impact of discrimination is partly captured by observable human capital and occupational characteristics.

16 To overcome the stated methodological problems, this study is novel in its approach to gather 17 original experimental data on gender differences in promotion opportunities and thereby lets - as argued by Duflo (2006) - "the research question determine the data to be obtained instead of the 19 data determining the questions that can be asked." More concretely, we send out 576 pairs of 20 fictitious job applications of individuals with about 5 years of job experience in their first and 21 current job to vacancies for jobs requiring at least some and at most 5 years of experience. The 22 two applications within each pair are similar, except for the revealed gender of the candidate, as 23 will be explained below. By monitoring the reaction from the employer side, unequal treatment 24 based on this single characteristic can be identified. This measure can be given a causal 25 interpretation because all the information the employer receives is under control of the 26 researcher so that selection on individual unobservables is eliminated. We send fictitious 27 applications to vacancies implying a promotion in terms of occupational level and/or job 28 authority compared with the current job of the candidate and to vacancies that are at the same 29 functional and authority level as the current job. Thereby, we are able to test whether unequal 
1 treatment of young men and women in the labour market is heterogeneous by whether or not 2 jobs imply a promotion in comparison with employees' current position. ${ }^{6}$ If employer 3 preferences contribute to Sticky Floors, unequal treatment of male and female job candidates

4 should be relatively more to the disadvantage of women who apply for a job implying a 5 promotion. This is our research hypothesis.

\section{The Experiment}

\section{Causal Evidence of Gender Discrimination by means of a Correspondence Experiment}

8 In order to answer our research question, we conducted a correspondence experiment. Within 9 this experiment, pairs of fictitious job applications were sent to real vacancies. The applications 10 within each pair were, as will be explained below, very comparable except for the gender of the 11 applicant. By monitoring the subsequent call-back from the employer side, discrimination based 12 on this single characteristic could be measured and given a causal interpretation.

13 Correspondence experiments are widely viewed as providing the most clean and compelling 14 evidence of unequal treatment in hiring (Riach and Rich, 2002). As argued in the introduction, 15 any bias introduced by individual unobservable characteristics is eliminated because all the 16 information received by the employer is controlled by the researcher. Strict equivalence between 17 the fictitious job candidates is realised and unequal treatment in respect of employers is 18 disentangled from other explanations of differential hiring outcomes such as differences in 19 human capital and preferences at the employee side.

\footnotetext{
${ }^{6}$ Stated otherwise, one can argue that a potential gender differential in call-back chances for a job implying a promotion at a new firm is comprised by a gender differential in hiring chances at a new firm and a gender differential in call-back for jobs implying a promotion. As we apply both for jobs implying a promotion and for jobs implying no promotion, our experimentally gathered data allows us to isolate the latter gender differential.
} 
1 Concerning the identification of gender discrimination, the extensive correspondence 2 experiment conducted by Neumark et al. (1996) is seminal. Neumark et al. (1996) showed that, 3 in the Philadelphian labour market for waiters and waitresses of 1994, female job candidates 4 had, compared to males, a substantially lower estimated probability of receiving an interview in 5 high-price restaurants and a substantially higher probability of receiving one in low-price 6 restaurants (where earnings were also lower). In the same realm, Albert et al. (2011), Booth and 7 Leigh (2010), Carlsson (2011), Firth (1982), Petit (2007), Riach and Rich (1987), Riach and 8 Rich (2006) and Weichselbaumer (2004) studied hiring discrimination based on gender in Spain, 9 Australia, Sweden, the United Kingdom, France and Austria by means of a correspondence 10 experiment. None of these studies, however, attempted to investigate heterogeneity in labour 11 market discrimination by whether or not the jobs for which the fictitious applicants applied 12 would imply a promotion.

13 We conducted our experiment between October 2013 and March 2014 in the labour market 14 of Flanders, the northern, Dutch-speaking part of Belgium. During this period we randomly selected 288 vacancies for jobs targeting Bachelors in business administration and 288 vacancies

16 for jobs targeting Masters in business economics in the database of the Public Employment 17 Agency of Flanders, the region's major job search channel. We restricted ourselves to vacancies 18 in the private sector requiring at most five years of work experience. ${ }^{7}$ Two job applications of 19 individuals with five years of work experience (in a first and current job), identical in terms of 20 productivity-relevant characteristics but different in their gender, were sent to the selected 21 vacancies. We opted for individuals with five years of experience because Sticky Floors are 22 related to the start of job ladder climbing. Moreover, jobs targeted at people with a tenure of five 23 years could be expected to be heterogeneous in promotion aspects compared to their current 24 (starters) job as "at least five years of work experience" is typically asked in (more) senior 25 positions.

\footnotetext{
${ }^{7}$ The database of the Public Employment Agency of Flanders covers both the private and public sectors. However, we were forced to restrict ourselves to vacancies in the private sector. This was the case since, in Flanders, vacancies in the public sectors almost always ask potential job candidates to provide the recruiter with formal proofs of their educational degrees. As we did not want to falsify these degrees, we were not able to apply for public sector vacancies.
} 
The data gathering process was reviewed and approved by the Ethical Committee of the

2 Faculty of Economics and Business Administration of Ghent University at its meeting of 9 July

32013.

\section{Construction of Fictitious Applications}

5 For each of the aforementioned academic degrees held by our fictitious applicants, we created two template applications comprising a resume and a motivation letter. We will refer to these

7 (template) applications as the Type A and Type B applications. These types were equal in all 8 productivity-relevant characteristics (such as educational qualifications, language skills and 9 computer skills). However, to avoid detection of the experiment, they differed in lay-out and 10 details. For instance, both candidates mentioned sports and cultural activities but the Type A 11 applicant referred to general sports activities and (drama club) acting while the Type B applicant 12 referred to fitness and tennis activities and playing saxophone. To ensure that our job 13 applications were realistic and representative, example applications of the Public Employment 14 Agency of Flanders were used and calibrated for our purposes.

The Type A and Type B applicants were single individuals born, studying and living in comparable suburbs of Ghent, the second largest city of Flanders. These candidates graduated

17 from tertiary education in June 2008 without any grade retention experience. In line with the 18 vacancy to which the pair of applicants was sent, a specialisation was chosen. ${ }^{8}$ All of the 19 applicants had graduated from University College Ghent (Bachelor in business administration) 20 or Ghent University (Master in business economics). Since September 2008, the fictitious 21 applicants were employed in a starters job in line with their academic degree and specialisation 22 and with no job authority (see below for how we define the concept of job authority). ${ }^{9}$

\footnotetext{
${ }^{8}$ For the Bachelor in business management, the specialisations used were: (i) accountancy and tax, (ii) finance and assurance, (iii) management of small- or medium-sized business, (iv) logistics, (v) marketing and (vi) legal practice. For the Master in business economics, the specialisations used were: (i) accountancy, (ii) finance and (iii) marketing.

${ }^{9}$ The professions of "accountant" (ISCO-08 code 3313), "file administrator assurances" (code 4312), "management assistant” (code 3343), "legal file administrator" (code 3411), "dispatcher" (code 3331) and "junior marketer" (code 3322) were used.
} 
Furthermore, we added to the Type A and Type B applications the following characteristics: Belgian nationality, driver's license, adequate IT skills, Dutch mother tongue, adequate English and French language skills and sports and cultural activities. In their motivation letters, the job

4 candidates indicated they were highly interested, motivated and organised. Lastly, we appended

5 a fictitious postal address (the combination of a real street in a middle-class neighbourhood and a non-existent street number) and a date of birth to all application templates.

\section{Randomised Disclosure of Applicants' Gender}

8 To erase any dependence of gender differentials in call-backs on the application type, a typically male and a typically female sounding name were alternately assigned to the Type A and Type B applications. An appendix with the four combinations of resumes (Type A with female name;

11 Type A with male name; Type B with female name; and Type B with male name) for one of the 12 educational degrees (Bachelor in business administration with accountancy and tax as a specialisation) is available online (Online Appendix A).

We sent the applications in an alternating order to the selected job postings, with a one-day delay in between. This resulted in a randomisation procedure in which we alternated between four pairs of applications: (i) first the Type A application with the female name and then (one

17 day later) the Type B application with the male name; (ii) first the Type A application with the 18 male name and then the Type B application with the female name; (iii) first the Type B application with the male name and then the Type A application with the female name; (iv) first the Type B application with the female name and then the Type A application with the male 21 name. To the first vacancy combination (i) was sent, to the second vacancy combination (ii), to

22 the third vacancy combination (iii), to the fourth vacancy combination (iv), to the fifth vacancy 23 again combination (i) and so on. This randomisation procedure was carried through for each of 24 the two educational degrees separately.

25 We chose "Elke De Vos" and "Anke De Vriendt" as the names of the female candidate 26 holding a Bachelor and the one holding a Master, respectively, and "Stijn Van Lancker" and 27 "Stijn Van De Voorde" as the names of the male candidates. We made sure that the chosen 
names did not represent a different social background following Bloothooft and Onland (2011) who linked the suffix of the name Dutch speaking parents choose for their children with these children's later wages.

We matched to each assigned name a mobile phone number and an email address. The voicemail messages were the telecommunication providers' standard (Dutch) messages ("Hello, [Name of the fictitious candidate] cannot answer your call. Please leave a message after the tone"). The names of the fictitious candidates were recorded by young people with a similar social-economic background (i.e. native students in the Master in (business) economics at Ghent University). The email addresses were registered with large and commonly used providers. All fictitious job applications were sent to the selected real vacancies by email. In view of avoiding detection, we applied to no more than one job posting from the same employer.

Measurement of Call-back

13 Call-backs were received by telephone voicemail and by email. As we mentioned postal 14 addresses with non-existent street numbers in the applications, we could not measure reactions 15 from the employer side by regular mail. However, several Flemish human resource managers 16 confirmed that, nowadays, employers rarely invite job candidates to selection interviews through 17 the latter channel. To minimise inconvenience to the employers, we immediately declined 18 positive call-back. By analogy with the corresponding testing literature, all reactions from the employer side received later than 30 days after sending out the applications were discounted. However, as we did not receive any positive reaction after 30 days, this turned out to be a 21 redundant restriction.

22 In our data-analysis, we distinguish between two definitions of positive call-back. Positive 23 call-back in a strict sense is defined as getting an invitation for an interview concerning the job 24 for which one applied - this definition was adopted by, e.g., Bertrand and Mullainathan (2004). 25 Positive call-back in a broad sense includes, in addition to the former definition, the request to 26 provide more information or to contact the employer or the receipt of an alternative job proposal 27 - this definition was adopted by, e.g., Kaas and Manger (2012). 
1 Variation in Occupational Level and Job Authority

2 Sticky Floors may translate into lower probabilities for females to make promotion in four

3 dimensions: occupational level, job authority, wages and non-statutory benefits (Deschacht et al.,

4 2011). As the two latter job aspects are not mentioned in the job postings in the database of the

5 Public Employment Agency of Flanders, our experiment does not allow observing these aspects

6 at the vacancy level. Therefore, we will focus on promotions in terms of occupational levels and

7 the degree of job authority. However, at the end of the regression analysis below we will include

8 the average wage in the occupation as a proxy for the wage in the posted job as a variable

9 explaining call-back rates by gender.

10 Each of the 576 vacancies to which we sent two fictitious job applications was matched with 11 an indicator of the occupational level and with an indicator of the job authority level. This was 12 done immediately after sending out the first application to a selected vacancy (and ipso facto 13 before call-back was received). On the one hand, based on the information in the vacancy, all 14 vacancies were matched with an occupation in the ISCO-08 classification system - ISCO-08 is 15 the second-generation International Standard Classification of Occupations, based on a 16 resolution of experts on labour statistics held in December 2007 and endorsed by the Governing 17 Body of the International Labour Organization (ILO) in March 2008. More concretely, we 18 searched a best match between the name of the vacancy (i.e. the name of the job) and the 19 description of the tasks within the job in the vacancy on the one hand and four elements 20 mentioned in the ISCO-08 group definitions file 21 (http://www.ilo.org/public/english/bureau/stat/isco/docs/gdstruct08.xls) on the other hand: 22 definition, tasks included, included occupation names and excluded occupation names. A new 23 job at a higher ISCO-08 1-digit-level - to which we will refer in the remainder of this article as 24 its "occupational level" - than the current one was defined as a promotion in terms of 25 occupational level. ${ }^{10}$

\footnotetext{
${ }^{10}$ The reader will notice that, due to our choice of the candidates current job and our procedure of matching these candidates with vacancies, both the current job and the job for which one applied were closely related to their academic degree and their specialisation. So, observed (potential)
} 
On the other hand, the jobs for which our fictitious job candidates applied were classified in three categories concerning job authority following Hachen (1990): jobs with no supervision authority, i.e. no supervision or coordination tasks concerning the work of other workers (level

4 1); jobs with supervision authority but no influence on the wage or promotion opportunities of 5 other workers (level 2); and jobs with both supervision authority and influence on the wage or promotion opportunities of other workers (level 3). As the current job of the candidates was at level 1, a new job with at least supervision authority (i.e. at level 2 or level 3) was defined as a promotion.

\section{$9 \quad$ Limitations of the Experimental Design}

Before answering our research question by means of a statistical analysis of the gathered data, in this subsection, we discuss some limitations of our experimental research setting.

First, our design can be effective only in demonstrating gender discrimination in the first stage of the recruitment process. Because we simply analyse the content of first call-backs, we cannot translate our empirical results into divergences in job offers. Bertrand and Mullainathan (2004) however argue that, even in the case the recruitment process has moderate friction, one could expect that reduced interview chances translate into reduced job offer chances. Second, our design is limited in its focus on promotion transitions to other firms. Unequal opportunities in promotion transitions within firms, which cannot be investigated by means of an experiment in the sense of the one outlined in this section, may be characterised by other dynamics. Third, we test for unequal treatment only within the vacancies targeted at individuals with a Bachelor's or Master's degree in business posted in the database of the Public Employment Agency of

\footnotetext{
occupational transitions are in rule vertical movements (i.e. transitions in job level) and not horizontal movements (i.e. transitions in job content). This is a desirable situation as, therefore, promotions in occupational level following our definition may not reflect non-promotional horizontal transitions. The most common promotions in occupational level observed in our data are those from accountant (ISCO-08 1-digit-level 3) and file administrator assurances (level 4) to financial professional (level 2); from management assistant (level 3) and legal file administrator (level 3 ) to administration professional (level 2); from dispatcher (level 3) to manufacturing, mining, construction and distribution manager (level 1); and from junior marketer (level 3) to sales, marketing and public relations professional (level 2).
} 
1 Flanders. It is possible that unequal treatment based on gender is more (or less) apparent among

2 employers who rely on other channels (such as social networks) for filling their vacancies or

3 among employers who have to fill vacancies targeted at other profiles. However, we are

4 specifically interested in the relationship between hiring discrimination against women and the

5 potential promotion implied by the jobs for which they apply. As this third limitation causes, by

6 construction, a similar shift in the discrimination measures for the selected jobs implying a

7 promotion and for those implying no promotion, our main research conclusions remain valid.

8 Fourth, the occupational level and job authority promotion dimensions defined in the

9 previous section may correlate with each other and with other vacancy characteristics. As a 10 consequence, descriptive statistics on heterogeneity in discrimination by these promotion 11 dimensions of the tested jobs might reflect heterogeneity of gender discrimination by other

12 dimensions. Therefore, we merge the gathered data with administrative data at the occupation-, 13 firm- and sector-level and analyse the merged data by means of a regression analysis controlling 14 for potential confounders.

\section{Results}

\section{Descriptive Data Analysis}

17 Table 1 and Table 2 describe the experimentally gathered data adopting the strict and broad 18 definition of positive call-back respectively. We provide the reader with two frequently used 19 statistical measures: the Positive Call-back Ratio (PCR) and the Net Discrimination Rate 20 (NDR) (Bertrand and Mullainathan, 2004; Neumark et al., 1996; Riach and Rich, 2002).

21 Overall, in 88 (195) of the 576 vacancies at least one candidate received a positive call22 back in strict sense (in broad sense). 32 (98) cases resulted in a positive call-back for both 23 candidates, 31 (51) in a positive call-back for just the male candidate and 25 (46) in a positive 24 call-back for the female candidate only. The overall PCR is obtained by dividing the total 
1 percentage of applications for which male candidates received a positive call-back by the

2 corresponding percentage for the female candidates. At the level of the total dataset, the

3 positive call-back rate following the strict sense (broad sense) definition is $11 \%^{11}(26 \%)$ for

4 male candidates and 10\% (25\%) for female candidates. The resulting PCR is 1.11 (1.03),

5 indicating that the male candidates got on average $11 \%(3 \%)$ more positive call-back in

6 reaction to their applications. These ratios are not significantly different from one and so we

7 conclude that, overall, employers did not discriminate based on sex.

8
[[Table 1 about here]].

[[Table 2 about here]]. 11

To provide the reader with an initial answer to our research question, we split our sample by the two aforementioned dimensions of promotion. First, we find significant evidence for unequal treatment against females when they applied for jobs at a higher ISCO-08 level than the level of their current job. In this case, the call-back ratio is 1.50 (1.23) saying that males got about $50 \%$ more invitations for a job interview (23\% more positive reactions in broad sense). Stated otherwise, when applying for these jobs, women got about 33\% less interview invitations and 19\% less positive reactions in broad sense. This finding is in line with our first research hypothesis of more hiring discrimination against women when they apply for jobs implying a promotion. Second, we find no significantly unequal treatment for both subsamples by the promotion dimension related to job authority.

The overall NDR is calculated by subtracting the number of applications for which the female candidate was preferred from the number of applications for which the male candidate was preferred and dividing the result by the number of pairs in which at least one candidate received a positive call-back. The result is a net measure of the number of discriminatory acts

\footnotetext{
${ }^{11} 0.11=(32+31) / 576$
} 
1 a female applicant could expect to encounter per application for which at least one candidate

2 received a positive call-back. Overall, the NDR is 0.07 (0.03) adopting the strict sense (broad

3 sense) definition of positive call-back. Based on a standard $\chi^{2}$ test, we cannot reject the

4 hypothesis that the candidates of both sexes were treated unfavourably equally often.

5 However, if the NDR is broken down by the occupational level and job authority promotion

6 dimensions, we get results in line with those based on the PCR.

7 An explanation for the finding of no significant heterogeneity in the job authority

8 dimension could be that for supervising positions (i.e. rather middle-management than

9 management) soft and social (leading) skills which are often related to women outweigh the

10 aforementioned more "masculine" characteristics, mentioned in the introduction, in respect of 11 employers.

\section{Regression analysis}

13 As, by construction, both the male and female candidate exhibit the same observable 14 characteristics per vacancy, regressing positive call-back on the gender of the candidate (and 15 vacancy and employee characteristics) leads to the same empirical conclusion as the one based 16 on Panel A of Table 1 and Table 2. On the other hand, as mentioned above, the occupational 17 level and job authority promotion dimensions may correlate with each other and with other 18 vacancy characteristics and, therefore, the results presented in Panel B and Panel C of Table 1 19 may in fact reflect heterogeneity of gender discrimination by other dimensions. Moreover, due to 20 the finite size of our data, the promotion indicators of the posted jobs may even correlate with 21 the application type (A or B) to which the female candidate was assigned and with whether her

22 application was sent before or after the male application. Therefore, we further explore the 23 experimentally gathered data by means of a regression analysis. Summary statistics of the 24 variables used in this analysis are outlined in Table 3. 
Table 4 and Table 5 present our regression results. We regress, by means of a linear probability model, the probability of positive call-back on various sets of key and control 4 variables, included as such and in interaction with female sex of the candidate. ${ }^{12}$ For reasons of 5 comparability of the regression results, all explanatory variables that are interacted with "Female candidate" are normalised by subtracting the mean among the subpopulation of female candidates and, for continuous variables, by dividing the result by the standard deviation among

8 this subpopulation. The estimation results for all variables interacted with female sex of the 9 candidate are presented in Table 4 (using positive call-back in strict sense as an outcome) and 10 Table 5 (using positive call-back in broad sense as an outcome). ${ }^{13}$ For each of the presented 11 models we computed multicollinearity diagnostics leading to variance inflation factors lower 12 than five, except for some sector dummies. In what follows, we first focus on the results of Table 134 and then compare these results with the ones in Table 5.

\section{[[Table 4 about here]].} gender of the candidate (model (1)); female sex of the candidate and a dummy indicating the posted job implied a promotion in occupational level, included as such and in interaction with

21 female sex (model (2)); and female sex of the candidate and a dummy indicating the posted job

22 implied a promotion in job authority, included as such and in interaction with female sex (model 23 (3)). By construction, the estimations presented in columns (1), (2) and (3) of Table 4 reflect 24 those presented in Panel A, Panel B and Panel C of Table 1. For instance, based on column (1),

\footnotetext{
${ }^{12}$ We also performed estimations with vacancy fixed-effects and probit estimations. The results for these exercises are closely comparable to those presented in the main text and are available on request.

${ }^{13}$ We do not present the main effects for these variables for reasons of concision.
} 
1 we learn that revealing a female gender lowers the chance on an invitation for a job interview 2 with about one percentage point, which squares with the comparison of the positive call-back rates for males $(11 \%)$ and females $(10 \%)$ mentioned in the previous subsection. Furthermore,

4 column (2) indicates that the gender gap in job interview invitation is about six percentage points 5 higher (and relatively more to the detriment of females) in jobs implying a promotion in 6 occupational level compared to jobs implying no promotion in this respect.

7 Next, in model (4), we combine the explanatory variables included in model (2) and model 8 (3). As a consequence, the finding of less positive call-back for women when they apply for jobs at a better ISCO level is even enforced. On the other hand, the coefficient for the interaction with the job authority promotion dimension increases and even turns positive, albeit insignificantly 11 so. This is due to the positive correlation between the variables indicating a promotion in the occupational level and job authority dimensions (Pearson $\mathrm{r}=0.56$ ). Clearly, when not controlling for the former interaction, the latter interaction picks up part of the fact that hiring chances are lower for women in jobs implying a promotion in occupational level.

In model (5), we extend the set of variables included as such and in interaction with female sex of the applicant. On the one hand, to control for the aforementioned potential correlation 17 between these variables and the promotion indicators of the selected jobs, we include variables indicating applications that were the first one of the pair sent to the vacancy and that used the Type B template - as the templates differ by academic degree, we adopt a Type B dummy for 20 each degree.

21 On the other hand, we include a set of variables capturing employee and vacancy 22 characteristics which may affect call-back rates and may be correlated, at least due to the finite 23 size of our data, with the promotion indicators of the posted jobs (see Table 3). First, we include 24 an indicator of the education level of the applicant (a dummy indicating a Master's degree) as both theoretical and empirical studies show that discrimination decreases with the level of education (Baert et al., 2015; Bursell, 2007; Taubman and Wales, 1974; Wood et al., 2009).

27 Second, we adopt variables indicating temporary and part-time contracts, as uniformly mentioned in the vacancies in the database of the Public Employment Agency of Flanders. If females have a relatively higher access to temporary and part-time jobs and these kinds of jobs 
1 are less present in the tested vacancies implying a promotion in occupational level - Table 3

2 shows that this is the case - this could drive the results presented in Panel B of Table 1. Third, 3 and related to the recent theory of erotic capital as a personal asset besides economic, cultural 4 and social capital and the empirical evidence on gender differentials in labour market 5 discrimination (Baert, 2014; Hakim, 2010), we add a proxy for the gender of the key decision 6 maker in the first stage of the recruitment procedure, i.e. the gender of the mentioned contact 7 person in the vacancy. Fourth, we include, from model (5) on, the natural logarithm of the 8 average number of workers in the firm in 2010 as a proxy of its size. ${ }^{14}$ We do this as some 9 former contributions to the empirical literature on labour market discrimination against ethnic 10 minorities report a negative relationship between firm size and hiring discrimination related to 11 the fact that larger firms are more likely to have a dedicated human resources function and have 12 therefore, on average, more standardised procedures for recruitment (Kaas and Manger, 2012; 13 Wood et al., 2009). Fifth, we include the fraction of female workers in the job as one could 14 expect that, as typically male (female) characteristics are (perceived as) particularly productive in traditionally male (female) occupations, unequal treatment should be more in favour of 16 women in female-dominated occupations (Booth and Leigh, 2010; Weichselbaumer, 2004). ${ }^{15}$

17 Sixth, to erase any correlation between the promotion indicators of the selected jobs and the 18 (other) characteristics of the sectors in which they were selected, we include 2-digit sector 19 dummies. ${ }^{16}$ In total, 57 sectors are represented in the data. As is the case for all other mentioned 20 variables, these dummies are included both as such and in interaction with female sex of the 21 candidate.

22 Column (5) of Table 4 shows the estimation results for model (5). We observe a substantial 23 but insignificant coefficient with the expected sign for the interaction between female sex of the

\footnotetext{
${ }^{14}$ This proxy was obtained from the Bel-first database (Bureau Van Dijk) after looking up the company number of the firm in the databases of the Flemish business magazine Trends and the Belgian organisation of Self-Employed and Small and Medium Sized Enterprises UNIZO.

${ }^{15}$ This variable is proxied by the average proportion of females in each occupation, following the ISCO-08 classification, in the European Social Survey (sixth round).

${ }^{16}$ We use the Statistical Classification of Economic Activities in the European Community ("NACE") at the 2-digit-level. The sector code was, based on the name and the address of the firm mentioned in the vacancy, found in the aforementioned databases of Trends and UNIZO.
} 
1 candidate and the variable "Temporary contract". More importantly, however, is that the

2 estimate for the interaction between female sex of the candidate and the dummy indicating

3 occupational level promotion jobs hardly changes by introducing the mentioned variables. We

4 also run model (5) without sector dummies leading to very similar results, which are available on

5 request.

6 Last, in model (6) we extend the set of explanatory variables included in model (5) with the 7 average wage in the job following the ISCO-08 classification at the 3-digit level in $2010 .{ }^{17} \mathrm{We}$ 8 get, however, no significant coefficient for this variable. This may point in the direction of no 9 heterogeneity in gender discrimination by the wage of the offered job. Just as well, however, this 10 finding might be explained by the fact that the average wage in the job following the ISCO-08 11 classification is not a good proxy for the wage in the particular posted job. Moreover, even when 12 employer discrimination is as such not heterogeneous by the wage level in the occupation, one 13 could expect that our main finding of an unequal access for males and females to (better paid) 14 positions at a higher functional level should translate into gender differences in pay.

15 The results outlined in Table 5, using the broad sense definition of positive call-back as an 16 outcome variable, lead to the same conclusion concerning the interactions between female sex of 17 the candidate and the promotion indicators of the selected jobs. Thereby, we can conclude that 18 the regression analysis presented in the current subsection confirms the descriptive findings of 19 the former subsection.

\section{Conclusion}

21 In this study, we contributed to the literature by investigating the importance of employer 22 preferences in explaining Sticky Floors, i.e. the pattern that women are, compared to men, less

\footnotetext{
${ }^{17}$ Source: Directorate-general Statistics and Economic information of Belgium. We use the 2010 statistics since those of later years are not yet available.
} 
1 likely to start to climb the job ladder. It was novel in its approach to gather original experimental 2 data on gender differences in promotion opportunities. More concretely, we conducted a field 3 experiment in which pairs of fictitious job applications of male and female Bachelors in business 4 administration and Masters in business economics with about 5 years of work experience in their 5 first and current job were sent to real job postings in Belgium. As we sent applications to both 6 vacancies implying a promotion in terms of occupational level and/or job authority and to 7 vacancies at the same level, we were able to test whether unequal treatment of young men and 8 women in the labour market was heterogeneous by whether or not jobs imply a promotion in 9 comparison with employees' current position. We found significant evidence for hiring 10 discrimination against females when they applied for jobs at a higher occupational level. For 11 these jobs, females got, compared to males, about $33 \%$ less invitations for a job interview and $1219 \%$ less positive reactions in broad sense. On the other hand, we found no significant 13 heterogeneity in hiring discrimination by the job authority level of the posted job. In addition, 14 based on regression analysis, we also found no evidence for heterogeneity in equal treatment of males and females by the average wage in the occupation mentioned in the vacancy.

From a policy perspective, we cannot deny that our results point in the direction of 17 discrimination of young women, albeit only when they apply for jobs implying a promotion in occupational level. In Belgium, as in many other OECD countries, the legal framework to punish labour market discrimination is available, ${ }^{18}$ so that the main benefit seems to lie in a more 20 vigorous detection of unequal hiring chances for promotion jobs. One could investigate whether 21 this could not happen based on a systematic application of the method we have used in this 22 study. An alternative policy option, which can be introduced voluntarily by individual firms or 23 imposed by the government, is anonymising job applications. Åslund and Skans (2012) showed, 24 by means of a quasi-experiment in Gothenburg, that removing names from job applications may 25 indeed increase first call-back and job offers for female job candidates. However, Krause et al. 26 (2012) and Behaghel et al. (Forthcoming) argue that policy makers should be aware of

\footnotetext{
${ }^{18}$ See Bassanini and Saint-Martin (2008) for a detailed description of the legal and institutional anti-discrimination framework in 23 OECD countries.
} 
1 unintended effects of anonymised job applications (for instance with respect to affirmative

2 action $)^{19}$ and that - therefore - the method of implementation is crucial.

3 As employees at a higher occupational level imply higher investment and (temporary) exit 4 costs, our results may be related to the career penalty of motherhood (Budig and England, 2001; 5 Correll et al., 2007; Kmec, 2011; ). In this respect, broadening the concept of discrimination, to 6 include dimensions about how jobs are structured and rewarded that have a disparate impact on 7 mothers, could be fruitful. In addition, tax incentives could be provided to employers for 8 reintegrating women who return to their job after maternity leave.

9 Given our experimental design, our results can, by construction, not be explained by theories 10 of ("old-boys"-)networking and sector segregation (Forret and Dougherty, 2004; Groot and 11 Maassen van den Brink, 1996; Ludsteck, 2014). Although we cannot rule out the possibility that 12 these mechanisms contribute to Sticky Floors as well, our results suggest that awareness 13 campaigns targeted at these mechanisms will not be sufficient in fighting gender inequalities in 14 promotion opportunities.

\section{References}

Albert, Rocío, Lorenzo Escot, and José A. Fernández-Cornejo. 2011. A field experiment to study sex and age discrimination in the Madrid labour market. International Journal of Human Resource Management 22: 351-375.

Albrecht, James, Anders Björklund, and Susan Vroman. 2003. Is there a glass ceiling in 20 Sweden? Journal of Labor Economics 21: 145-177.

\footnotetext{
${ }^{19}$ While various developed countries (such as Australia, Belgium, France, Finland, Spain, New Zealand, and Norway) have imposed gender quotas on the boards of big public institutions and/or private companies, we are not aware of gender quotas to guarantee the access of women into middle-management positions (or lower) (Bertrand, 2014; Fagan et al., 2012).
} 
1 Altonji, Joseph G., and Rebecca M. Blank. 1999. Race and Gender in the Labor Market. In

2 O. Ashenfelter and D. Card (Eds.), Handbook of Labor Economics, pp. 3143-3259. Amsterdam: 3 Elsevier.

4 Arrow, Kenneth J. 1973. The Theory of Discrimination. In Orley Ashenfelter and Albert 5 Rees (Eds.) Discrimination in Labor Markets, pp. 3-33. Princeton: Princeton University Press.

6 Arulampalam, Wiji, Alison L. Booth, and Mark L. Bryan. 2007. Is there a glass ceiling over 7 Europe? Exploring the gender pay gap across the wage distribution. ILR Review 60: 163-186.

8 Aslund, Olof, and Oskar N. Skans, 2012. Do Anonymous Job Application Procedures Level 9 the Playing Field? ILR Review 65: 82-107.

10 Azmat, Ghazala, and Barbara Petrongolo. 2014. Gender and the Labor Market: What Have 11 We Learned from Field and Lab Experiments? Labour Economics 30: 32-40.

12 Baert, Stijn. 2014. Career Lesbians. Getting Hired for Not Having Kids? Industrial Relations 13 45: 543-561.

14 Baert, Stijn, Bart Cockx, Niels Gheyle, and Cora Vandamme. 2015. Is There Less 15 Discrimination in Occupations where Recruitment is Difficult? ILR Review 68: 467-500.

Baker, Joe G. 2003. Glass Ceilings or Sticky Floors? A Model of High-Income Law Graduates. Journal of Labor Research 24: 695-711.

Bassanini, Andrea, and Anne Saint-Martin. 2008. The price of prejudice: Labour market discrimination on the grounds of gender and ethnicity. In OECD, Employment Outlook. Paris: OECD.

1 Baumle, Amanda K. 2009. The cost of parenthood: Unraveling the effects of sexual orientation and gender on income. Social Science Quarterly 90: 983-1002.

Becker, Gary. 1957. The Economics of Discrimination. Chicago: University of Chicago Press.

Behaghel, Luc, Thomas Le Barbanchon, and Bruno Crépon. Forthcoming. Unintended Effects of Anonymous Resume. American Economic Journal: Applied Economics. 
Bergmann, Barbara R. 1989. Does the Market for Women's Labor Need Fixing? Journal of Economic Perspectives 3: 43-60.

Bertrand, Marianne, and Sendhil Mullainathan. 2004. Are Emily and Greg more employable than Lakisha and Jamal? A field experiment on labor market discrimination. American Economic Review 94: 991-1013.

Bertrand, Marianne, Sandra E. Black, Sissel Jensen, and Adriana Lleras-Muney. 2014. Breaking the Glass Ceiling? The Effect of Board Quotas on Female Labor Market Outcomes in Norway. NBER Working Paper Series No. 20256. Massachusetts: NBER.

Blandford, John M. 2003. The nexus of sexual orientation and gender in the determination of earnings. ILR Review 56: 622-642.

Blau, Francine, and Jed Devaro. 2007. New evidence on gender differences in promotion rates: An empirical analysis of a sample of new hires. Industrial Relations 46: 511-500.

Blinder, Alan S. 1973. Wage Discrimination: Reduced Form and Structural Estimates. Journal of Human Resources 8: 436-455.

Bloothooft, Gerrit, and David Onland. 2011. Socioeconomic determinants of first names. Names 59: 25-41.

Booth, Alison L. 2009. Gender and competition. Labour Economics 16: 599-606.

Booth, Alison L., Marco Francesconi, and Jeff Frank. 2003. A sticky floors model of promotion, pay, and gender. European Economic Review 47: 295-322.

Booth, Alison L., and Andrew Leigh. 2010. Do employers discriminate by gender? A field experiment in female-dominated occupations. Economics Letters 107: 236-238.

Borjas, George J. 2009. Labor Economics (New York, McGraw-Hill).

Budig, Michelle J., and Paula England. 2001. The Wage Penalty for Motherhood. American Sociological Review 66: 204-225.

Bursell, Moa. 2007. What's in a name? A field experiment test for the existence of ethnic discrimination in the hiring process. Stockholm University Linnaeus Center for Integration 
1 Studies Working Paper Series No. 2007-7. Stockholm: Stockholm University Linnaeus Center

2 for Integration Studies.

3 Carlsson, Magnus. 2011. Does hiring discrimination cause gender segregation in the Swedish

4 Labor Market? Feminist Economics 17: 71-102.

5 Carter, Nancy M., and Christine Silva. 2011. Does Doing All The Right Things Really Get

6 Women Ahead? New York: Catalyst.

7 Charles, Kofi K., and Jonathan Guryan. 2008. Prejudice and Wages: An Empirical 8 Assessment of Beckers The Economics of Discrimination. Journal of Political Economy 116: $9 \quad 773-809$.

10 Correll, Shelly J., Stephen Benard, and In Paik. 2007. Getting a Job: Is There a Motherhood 11 Penalty? American Journal of Sociology 112: 1297-1339.

Christofides, Louis N., Alexandros Polycarpou, and Konstantinos Vrachimis. 2013. Gender wage gaps, 'sticky floors' and 'glass ceilings' in Europe. Labour Economics 21: 86-102.

Darity, William A. Jr., and Patrick L. Mason. 1998. Evidence on Discrimination in 15 Employment: Codes of Color, Codes of Gender. Journal of Economic Perspectives 12: 63-90. manuscript.

Fagan, Colette, Maria González Menéndez, and Silvia Gómez Anson. 2012. Women on corporate boards and in top management: European trends and policy. Chippenham: Palgrave MacMillan.

Fang, Zheng, and Chris Sakellariou. 2011. A Case of Sticky Floors: Gender Wage Differentials in Thailand. Asia Economic Journal 25: 35-54.

Filippin, Antonio, and Andrea Ichino. 2005. Gender wage gap in expectations and realizations. Labour Economics 12: 125-145. 
Firth, Michael. 1982. Sex discrimination in job opportunities for women. Sex Roles 8: 8912901.

3 Forret, Monica L., and Thomas W. Dougherty. 2004. Networking behaviors and career 4 outcomes: differences for men and women? Journal of Organizational Behavior 25: 419-437.

5 Gradín, Carlos, and Coral del Río. 2009. Gender wage differentials in Spain: a distributional 6 approach by subpopulations. Hacienda Pública Española 189: 9-46.

7 Groot, Wim, and Henriette Maassen van den Brink. 1996. Glass ceilings or dead ends: Job 8 promotion of men and women compared. Economics Letters 53: 221-226.

9 Hachen, David S. 1990. Three Models of Job Mobility in Labor Markets. Work and 10 Occupations 17: 320-354.

11 Hakim, Catherine 2010. Erotic Capital. European Sociological Review 26: 499-518.

12 Kaas, Leo, and Christian Manger. 2012. Ethnic discrimination in Germany's labour market: 13 a field experiment. German Economic Review 13: 1-20.

14 Kassenboehmer, Sonja C., and Mathias G. Sinning. 2014. Distributional Changes in the 15 Gender Wage Gap. ILR Review 67: 335-361.

Kmec, Julie A. 2011. Are Motherhood Wage Penalties and Fatherhood Bonuses Warranted?

17 Social Science Research 40: 444-459.

18 Krause, Annabelle, Ulf Rinne, and Klaus F. Zimmermann. 2012. Anonymous job 19 applications in Europe. IZA Journal of European Labor Studies 1:5.

20 Ludsteck, Johannes. 2014. The Impact of Segregation and Sorting on the Gender Wage 21 Gap: Evidence from German Linked Longitudinal Employer-Employee Data. ILR Review 67: $22 \quad 362-394$.

23 Matteazzi, Eleonora, Ariane Pailhé, and Anne Solaz. 2014. Part-Time Wage Penalties for 24 Women in Prime Age. A Matter of Selection or Segregation? Evidence from Four European 25 Countries. ILR Review 67: 955-985.

26 Neumark, David, Roy Bank, and Kyle Van Nort. 1996. Sex Discrimination in Restaurant 
1 Hiring: An Audit Study. Quarterly Journal of Economics 111: 915-941.

2 Oaxaca, Ronald. 1973. Male-Female Wage Differentials in Urban Labor Markets. 3 International Economic Review 14: 693-709.

4 Oakley, Judith G. 2000. Gender-based Barriers to Senior Management Positions: 5 Understanding the Scarcity of Female CEOs. Journal of Business Ethics 27: 321-334.

6 Petit, Pascale. 2007. The effects of age and family constraints on gender hiring 7 discrimination: A field experiment in the French financial sector. Labour Economics 14: 3718391.

9 Reuben, Ernesto, Pedro Rey-Biel, Paola Sapienza, and Luigi Zingales. 2012. The emergence 10 of male leadership in competitive environments. Journal of Economic Behavior \& Organization 11 83: 111-117.

12 Riach, Peter A., and Judith Rich. 1987. Testing for Sexual Discrimination in the Labour 13 Market. Australian Economic Papers 26: 165-178.

14 Riach, Peter A., and Judith Rich. 2002. Field Experiments of Discrimination in the Market 15 Place. Economic Journal 112: 480-518.

16 Riach, Peter A., and Judith Rich. 2006. An Experimental Investigation of Sexual 17 Discrimination in Hiring in the English Labor Market. B.E. Journal of Economic Analysis \& 18 Policy 5: 1-22.

19 Romeu Gordo, Laura. 2009. Why Are Women Delaying Motherhood in Germany? Feminist 20 Economics 15: 57-75.

21 Smith, Nina, Valdemar Smith, and Mette Verner. 2013. Why are so few females promoted 22 into CEO and Vice President positions? Danish empirical evidence, 1997-2007. ILR Review 64: 23 949-980.

24 Taubman, Paul J., and Terence Wales. 1974. Higher Education and Earnings: College as an 25 Investment and Screening Device. Massachusetts: NBER Books.

26 Weichselbaumer, Doris. 2004. Is it Sex or Personality? The Impact of Sex Stereotypes on 
1 Discrimination in Applicant Selection. Eastern Economic Journal 30: 159-186.

2 Weinberger, Catherine, 2011. In Search of the Glass Ceiling: Gender and Earnings Growth 3 among U.S. College Graduates in the 1990's. ILR Review 64: 949-980.

4 Wood, Martin, Jon Hales, Susan Purdon, Tanja Sejersen, and Oliver Hayllar. 2009. A test for 5 racial discrimination in recruitment practice in British cities. DWP Research Reports, 607.

6 Yap, Margaret, and Alison M. Konrad. 2009. Gender and Racial Differentials in Promotions: 7 Is There a Sticky Floor, a Mid-Level Bottleneck, or a Glass Ceiling? Relations Industrielles8 Industrial Relations 64: 593-619. 
Table 1. The Probability of Positive Call-back in Strict Sense: Descriptive Analysis

\begin{tabular}{|c|c|c|c|c|c|c|c|c|c|}
\hline Data selection & $\begin{array}{l}\text { Jobs } \\
\text { (No.) }\end{array}$ & $\begin{array}{c}\text { Neither candidate } \\
\text { positive call-back } \\
\text { (No.) }\end{array}$ & $\begin{array}{c}\text { Both candidates } \\
\text { positive call-back } \\
\text { (No.) }\end{array}$ & $\begin{array}{c}\begin{array}{c}\text { Only male } \\
\text { positive call-back }\end{array} \\
\text { (No.) }\end{array}$ & $\begin{array}{c}\begin{array}{c}\text { Only female } \\
\text { positive call-back }\end{array} \\
\text { (No.) }\end{array}$ & PCR & $\mathbf{t}$ & NDR & $\chi^{2}$ \\
\hline \multicolumn{10}{|l|}{ A. All jobs } \\
\hline All jobs & 576 & 488 & 32 & 31 & 25 & 1.105 & 0.802 & 0.068 & 0.643 \\
\hline \multicolumn{10}{|c|}{ B. Breakdown by occupational level promotion dimension } \\
\hline Jobs at same level as current job & 248 & 206 & 18 & 9 & 15 & 0.818 & 1.226 & -0.143 & 1.500 \\
\hline Jobs at higher level than current job & 328 & 282 & 14 & 22 & 10 & $1.500 * *$ & 2.133 & $0.261 * *$ & 4.500 \\
\hline \multicolumn{10}{|c|}{ C. Breakdown by job authority promotion dimension } \\
\hline Jobs with no job authority & 328 & 271 & 21 & 20 & 16 & 1.108 & 0.666 & 0.070 & 0.444 \\
\hline Jobs with job authority & 248 & 217 & 11 & 11 & 9 & 1.100 & 0.447 & 0.065 & 0.200 \\
\hline
\end{tabular}

Notes. See subsection "Variation in Occupational Level and Job Authority" for a definition of the used promotion dimensions. The Positive Call-back Ratio (PCR) is calculated by dividing the percentage of applications for which male candidates received a positive call-back by the corresponding percentage for the female candidates. The t-test for the PCR tests the null hypothesis that the probability of positive call-back is the same for candidates from both gender groups. As two applicants contacted the same firm, the probability of the male applicant receiving an invitation correlates with the probability of the female applicant candidate receiving one. Therefore, standard errors are corrected for clustering of the observations at the vacancy level. The Net Discrimination Rate (NDR) is calculated by subtracting the number of applications for which the female candidate was preferred from the number of applications for which the male candidate was preferred and dividing by the number of pairs in which at least one candidate received a positive call-back. The chi-square test for the NDR tests the null hypothesis that both candidates are treated unfavourably just as frequently. *** $(* *)((*))$ indicates significance at the $1 \%(5 \%)((10 \%))$ significance level. 
Table 2. The Probability of Positive Call-back in Broad Sense: Descriptive Analysis

\begin{tabular}{|c|c|c|c|c|c|c|c|c|c|}
\hline Data selection & $\begin{array}{l}\text { Jobs } \\
\text { (No.) }\end{array}$ & $\begin{array}{c}\text { Neither candidate } \\
\text { positive call-back } \\
\text { (No.) }\end{array}$ & $\begin{array}{c}\text { Both candidates } \\
\text { positive call-back } \\
\text { (No.) }\end{array}$ & $\begin{array}{c}\begin{array}{c}\text { Only male } \\
\text { positive call-back }\end{array} \\
\text { (No.) }\end{array}$ & $\begin{array}{c}\begin{array}{c}\text { Only female } \\
\text { positive call-back }\end{array} \\
\text { (No.) }\end{array}$ & PCR & $\mathbf{t}$ & NDR & $\chi^{2}$ \\
\hline \multicolumn{10}{|l|}{ A. All jobs } \\
\hline All jobs & 576 & 381 & 98 & 51 & 46 & 1.035 & 0.507 & 0.026 & 0.258 \\
\hline \multicolumn{10}{|c|}{ B. Breakdown by occupational level promotion dimension } \\
\hline Jobs at same level as current job & 248 & 156 & 45 & 18 & 29 & 0.851 & 1.610 & -0.120 & 2.574 \\
\hline Jobs at higher level than current job & 328 & 225 & 53 & 33 & 17 & $1.229 * *$ & 2.277 & $0.155^{* *}$ & 5.120 \\
\hline \multicolumn{10}{|c|}{ C. Breakdown by job authority promotion dimension } \\
\hline Jobs with no job authority & 328 & 209 & 60 & 28 & 31 & 0.967 & 0.390 & -0.025 & 0.153 \\
\hline Jobs with job authority & 248 & 172 & 38 & 23 & 15 & 1.151 & 1.300 & 0.105 & 1.684 \\
\hline \multicolumn{10}{|c|}{$\begin{array}{l}\text { Notes. See subsection "Variation in Occupational Level and Job Authority" for a definition of the used promotion dimensions. The Positive Call-back Ratio (PCR) is calculated by dividing the } \\
\text { percentage of applications for which male candidates received a positive call-back by the corresponding percentage for the female candidates. The t-test for the PCR tests the null hypothesis that } \\
\text { the probability of positive call-back is the same for candidates from both gender groups. As two applicants contacted the same firm, the probability of the male applicant receiving a positive } \\
\text { reaction correlates with the probability of the female applicant candidate receiving one. Therefore, standard errors are corrected for clustering of the observations at the vacancy level. The Net } \\
\text { Discrimination Rate (NDR) is calculated by subtracting the number of applications for which the female candidate was preferred from the number of applications for which the male candidate } \\
\text { was preferred and dividing by the number of pairs in which at least one candidate received a positive call-back. The chi-square test for the NDR tests the null hypothesis that both candidates are } \\
\text { treated unfavourably just as frequently. } * * *(* *)((*)) \text { indicates significance at the } 1 \%(5 \%)((10 \%)) \text { significance level. }\end{array}$} \\
\hline
\end{tabular}


Table 3. Regression Variables (Employee and Vacancy Characteristics): Summary Statistics

\begin{tabular}{lccc}
\hline \hline & All jobs & Jobs implying a promotion in occupational level & Jobs implying a promotion in job authority \\
\hline First application sent within pair of female sex & $0.500(0.500)$ & $0.506(0.501)$ & $0.520(0.501)$ \\
Application Type B of female sex & $0.500(0.500)$ & $0.530(0.500)$ & $0.544(0.499)$ \\
Master's degree & $0.500(0.500)$ & $0.616(0.487)$ & $0.540(0.499)$ \\
Temporary contract & $0.127(0.333)$ & $0.116(0.321)$ & $0.109(0.312)$ \\
Part-time contract & $0.075(0.263)$ & $0.061(0.240)$ & $0.052(0.223)$ \\
Male recruiter & $0.325(0.469)$ & $1.501(1.085)$ & $0.270(0.445)$ \\
Log(average FTE in firm) & $1.472(1.048)$ & $0.497(0.163)$ & $1.510(1.003)$ \\
$\%$ female workers in occupation & $0.550(0.181)$ & $4,787(855.6)$ & $0.490(0.158)$ \\
Average wage in occupation in EUR & $4,098(1,043)$ & $66.86(17.29)$ & $4,813(1,066)$ \\
Sector number (NACE, 2-digit-level) & $65.54(17.51)$ & $66.32(17.31)$ & \\
\hline \hline
\end{tabular}

See subsection "Regression Analysis" for a definition of the listed variables. The reported statistics are averages and standard deviations in parentheses. 
Table 4. The Probability of Positive Call-back in Strict Sense: Regression Analysis

\begin{tabular}{|c|c|c|c|c|c|c|}
\hline & (1) & (2) & (3) & (4) & (5) & (6) \\
\hline Female candidate & $-0.010(0.013)$ & $-0.010(0.013)$ & $-0.010(0.013)$ & $-0.010(0.013)$ & $-0.012(0.013)$ & $-0.012(0.013)$ \\
\hline Female candidate * Promotion in occupational level (norm.) & & $-0.061 * *(0.026)$ & & $-0.092 * * *(0.035)$ & $-0.095^{* *}(0.040)$ & $-0.106 * *(0.049)$ \\
\hline Female candidate $*$ Promotion in job authority (norm.) & & & $0.004(0.026)$ & $0.055(0.034)$ & $0.067(0.041)$ & $0.063(0.044)$ \\
\hline Female candidate $*$ First application sent within pair (norm.) & & & & & $0.065(0.048)$ & $0.068(0.048)$ \\
\hline Female candidate * Application Type B, Master (norm.) & & & & & $0.061(0.063)$ & $0.061(0.063)$ \\
\hline Female candidate * Application Type B, Bachelor (norm.) & & & & & $0.046(0.072)$ & $0.044(0.071)$ \\
\hline Female candidate $*$ Master's degree (norm.) & & & & & $-0.030(0.053)$ & $-0.032(0.053)$ \\
\hline Female candidate $*$ Temporary contract (norm.) & & & & & $0.071(0.059)$ & $0.071(0.059)$ \\
\hline Female candidate $*$ Part-time contract (norm.) & & & & & $0.019(0.053)$ & $0.019(0.053)$ \\
\hline Female candidate $*$ Male recruiter (norm.) & & & & & $-0.003(0.035)$ & $-0.002(0.036)$ \\
\hline Female candidate $* \log ($ average FTE in firm) (norm.) & & & & & $0.017(0.017)$ & $0.017(0.017)$ \\
\hline Female candidate $* \%$ female workers in occupation (norm.) & & & & & $-0.003(0.017)$ & $-0.002(0.017)$ \\
\hline Female candidate $*$ Average wage in occupation (norm.) & & & & & & $0.009(0.024)$ \\
\hline Linear probability model & Yes & Yes & Yes & Yes & Yes & Yes \\
\hline Dependent variable: invitation to a job interview & Yes & Yes & Yes & Yes & Yes & Yes \\
\hline Sector fixed effects interacted with female candidate & No & No & No & No & Yes & Yes \\
\hline Observations & 1152 & 1152 & 1152 & 1152 & 1074 & 1074 \\
\hline
\end{tabular}

Notes. See subsections "Variation in Occupational Level and Job Authority" and "Regression Analysis" for a definition of the variables adopted in the regressions. The variables that are interacted with "Female candidate" are also included without interaction with this variable. Except for "Female candidate", all variables are normalised (norm.) by subtracting the mean among the population of female candidates. Continuous variables are further normalised by dividing by the standard deviation among this subpopulation. Standard errors, corrected for clustering at the vacancy level, are in parentheses. *** $(* *)\left(\left(^{*}\right)\right)$ indicates significance at the $1 \%(5 \%)((10 \%))$ level. From model $(5)$ on, 78 observations are dropped due to missing values for the added control variables. 
Table 5. The Probability of Positive Call-back in Broad Sense: Regression Analysis

\begin{tabular}{|c|c|c|c|c|c|c|}
\hline & (1) & (2) & (3) & (4) & $(\mathbf{5})$ & (6) \\
\hline Female candidate & $-0.009(0.017)$ & $-0.009(0.017)$ & $-0.009(0.017)$ & $-0.009(0.017)$ & $-0.010(0.018)$ & $-0.010(0.018)$ \\
\hline Female candidate * Promotion in occupational level (norm.) & & $-0.093^{* * *}(0.035)$ & & $-0.102 * *(0.043)$ & $-0.085^{*}(0.051)$ & $-0.109 *(0.062)$ \\
\hline Female candidate $*$ Promotion in job authority (norm.) & & & $-0.041(0.034)$ & $0.015(0.042)$ & $0.034(0.049)$ & $0.025(0.052)$ \\
\hline Female candidate $*$ First application sent within pair (norm.) & & & & & $0.160 * *(0.069)$ & $0.163^{* *}(0.070)$ \\
\hline Female candidate * Application Type B, Master (norm.) & & & & & $0.092(0.097)$ & $0.093(0.097)$ \\
\hline Female candidate * Application Type B, Bachelor (norm.) & & & & & $0.053(0.102)$ & $0.051(0.102)$ \\
\hline Female candidate $*$ Master's degree (norm.) & & & & & $-0.042(0.080)$ & $-0.046(0.080)$ \\
\hline Female candidate $*$ Temporary contract (norm.) & & & & & $0.059(0.089)$ & $0.059(0.090)$ \\
\hline Female candidate $*$ Part-time contract (norm.) & & & & & $-0.005(0.074)$ & $-0.006(0.074)$ \\
\hline Female candidate $*$ Male recruiter (norm.) & & & & & $-0.067(0.046)$ & $-0.066(0.046)$ \\
\hline Female candidate $* \log ($ average FTE in firm) (norm.) & & & & & $-0.003(0.022)$ & $-0.002(0.022)$ \\
\hline Female candidate $* \%$ female workers in occupation (norm.) & & & & & $0.028(0.020)$ & $0.032(0.021)$ \\
\hline Female candidate * Average wage in occupation (norm.) & & & & & & $0.021(0.031)$ \\
\hline Linear probability model & Yes & Yes & Yes & Yes & Yes & Yes \\
\hline Dependent variable: any positive reaction & Yes & Yes & Yes & Yes & Yes & Yes \\
\hline Sector fixed effects interacted with female candidate & No & No & No & No & Yes & Yes \\
\hline Observations & 1152 & 1152 & 1152 & 1152 & 1074 & 1074 \\
\hline
\end{tabular}

Notes. See subsections "Variation in Occupational Level and Job Authority" and "Regression Analysis" for a definition of the variables adopted in the regressions. The variables that are interacted with "Female candidate" are also included without interaction with this variable. Except for "Female candidate", all variables are normalised (norm.) by subtracting the mean among the population of female candidates. Continuous variables are further normalised by dividing by the standard deviation among this subpopulation. Standard errors, corrected for clustering at the vacancy level, are in parentheses. *** $(* *)((*))$ indicates significance at the 1\% (5\%) ((10\%)) level. From model (5) on, 78 observations are dropped due to missing values for the added control variables. 